\title{
STUDY ON THE SURVEY, IDENTIFICATION CRITERIA AND TOOL SYSTEM OF HISTORICAL BUILDINGS SUPPORTED BY THE TECHNOLOGY OF GIS
}

\author{
Kangning Liu ${ }^{1}$, Yang Xue ${ }^{1}$, Danyu Zhao ${ }^{1}$, Zhongyuan Huang ${ }^{1}$ \\ ${ }^{1}$ Beijing Tsinghua Tongheng Urban Planning \& Design Institute, People's Republic of China - (3208404609, 411514364, \\ 517641829,676875024)@qq.com
}

Commission II, WG II/8

KEY WORDS: Historical architecture, Census and Identification, GIS and Secondary development, Standardization, Data, Internet

\begin{abstract}
:
Historical architecture is of great significance to the continuation of urban historical context, and it is an important part of cultural heritage. The general survey and identification of historical buildings is the basis and support of the protection and utilization of historical buildings. However, the existing working methods and technical means are relatively backward, it can not reflect and record the value characteristics and basic information of historical buildings truly and completely. These backward means have led to the inefficiency of the general survey and identification of historical buildings, which has also led to the fact that the results of the general survey can not be digitized and difficult to refer to. This paper analyzes the problems existing in the traditional methods of general survey and identification of historical buildings, and constructs the basic technical support of the general survey and identification of historical buildings from the aspects of general survey and identification standard system, investigation and data processing tool system, operation guidance system and so on, which is based on the technical requirements and the secondary development of GIS, taking the general survey and identification of historical buildings in Beijing as an example. It is hoped that this paper can convey our thinking and research results to our professional colleagues. In addition, we look forward to the promotion and application of this method, so as to promote the protection and management of cultural heritage towards comprehensive data.
\end{abstract}

\section{RESEARCH BACKGROUND AND PROBLEM ANALYSIS}

\subsection{Research Background}

1.1.1 The Central Government Attaches Great Importance to the Construction of Chinese Cultural Self-confidence in the New Era, and Strengthening the Protection of Historical and Cultural Heritage has Become an Important Starting Point of Cultural Construction.

In China, the CPC Central Committee and the State Council have always attached importance to the protection of historical buildings. At the 19th National Congress of the CPC Central Committee, it was put forward that it was necessary to build the cultural self-confidence of the Chinese nation in the new era. In General Secretary Xi Jinping's strategy of governing the country, the protection of history and culture has been promoted to an unprecedented important position. General Secretary Xi Jinping pointed out: we should protect the cultural heritage left by our predecessors properly, including cultural relics, famous historical and cultural cities, towns and villages, historical and cultural blocks, historical buildings, industrial heritage, and intangible cultural heritage. We should protect both ancient and modern buildings. In addition, it is necessary to protect not only single buildings, but also street blocks and urban patterns.

1.1.2 The Ministry of Housing and Construction has Carried Out Pilot Work on Historical Buildings and Strengthened the Protection of Historical buildings.

Historical architecture is an important carrier of Chinese excellent culture. The protection and utilization of historical buildings is of great significance to continue the historical context of the city, protect the traditional style and improve the quality of the city. There are a large number and wide distribution of historical buildings in China. In 2017, the Ministry of Housing and Construction issued a notice on the first batch of pilot cities for the protection and utilization of historical buildings, and Beijing is the only municipality to be chosen. The circular clearly covers six pilot tasks, such as census and identification, protection and utilization and so on. Among them, the general survey of historical buildings is the basis and support of this work, and it is the key factor affecting the protection of historical buildings in the future.

1.1.3 The Construction of Database and Digital Intelligent Management Platform related to Historical Buildings will Become the Inevitable Requirement of Urban Management in the New Era.

In the report of the 19th CPC National Congress, General Secretary Xi Jinping proposed to promote the deep integration of the Internet, big data, artificial intelligence and the real economy, and build a digital China and an intelligent society. City is the most active area of social development, so the construction of intelligent city is an important part of building intelligent society, and the spatio-temporal big data platform is the basic support of the construction and operation of intelligent city (Xu, H., Yang, L.X., Fang, Z.X., 2002).

In January 2019, the Ministry of Natural Resources of the people's Republic of China issued a notice entitled "Technical outline for the Construction of a spatio-temporal big data platform for Smart cities (2019 Edition)," upgrading the construction of smart cities to a global strategic height. Historical architecture is an inseparable part of the city, the formation of historical building-related information database 
and the establishment of management platform will become the inevitable requirement of intelligent city construction.

\subsection{Analysis of Issue}

1.2.1 There are defects in the working methods of the general survey and identification of traditional historical buildings, which lack the necessary modern technical support.

In the 13th five-year Plan of the Ministry of Housing and Construction, it is emphasized that the management of famous historical and cultural cities should be strengthened. However, it can only use backward technical means in the inspection of famous cities, such as, the use of paper results for on-site comparison. At present, there are shortcomings in the technical means of the protection of historical buildings.

Research tools are backward. At present, the general survey of historical buildings mainly depends on a large number of investigators through paper planning drawings, cameras, paper and pen records and other traditional ways. The degree of automation is low, the work efficiency is low, the manpower is huge, the error rate is high, and the integrity of census results is low.

It is difficult to unify the standard of work. Because the professional knowledge and technical level of a large number of investigators are different, the previous standard training is difficult. In the work of general survey, the work style, the work habit and the specialized knowledge of the staff are different, so they have different degrees of implementation of the survey standards, resulting in the format of survey results is not unified and the results are not perfect. It brings difficulties for the follow-up data processing, preservation, general survey and identification. Furthermore, it is difficult to bring strong followup support for the protection and management of historical buildings.

There is a risk of leakage. Once the traditional census method is not standardized, it will also bring serious problems such as data leakage, data loss and so on. Ensuring the security, standardization and correctness of historical building data and improving the efficiency of census are common challenges faced by historical building management institutions and conservation planning and design units.

1.2.2 Because of the Huge Quantity and Diverse Forms of the Historical Building Information, the Traditional Historical Building Archives are Unable to Meet the Needs of Collection, Storage and Output of Historical Building Information.

The number of historical buildings is huge, preservation forms, preservation elements are diverse, the traditional recording means can not meet the requirements of comprehensive information collection, can not fully reflect the value of historical buildings. The number of historical buildings in small historical cities is about hundreds, and the number of large cities may reach thousands, and the number of such historical cities in China is huge. For each historical building, the preservation elements, characteristic parts, value elements and other forms are also complex and diverse. In addition, the property rights, age, quality and other information related to historical buildings also need to be recorded. The traditional historical building archives only record simple information and take some photos, it is difficult to record the historical information as a whole, so it can not fully reflect the value of historical buildings, which also lays hidden dangers for the protection and utilization of historical buildings in the future.

The unified historical building database standard is lack, and the historical building basic data is missing. For a variety of reasons, various places have also tried to collect and manage the complicated historical building data in the form of data, but this work has not been carried out smoothly. The fundamental reason is that there is no unified and standardized historical building database standard. Collecting information in the form of data must require the accuracy and standardization of data. If there is no standardized database, the corresponding standardized data collection can not be carried out, and it will inevitably lead to the lack of basic information of historical buildings.

The general survey and identification of historical buildings is the basis of the protection and management of historical buildings. The protection elements, such as historical buildings and ancillary structures, have the characteristics of large number, various categories, complex structure, diversification of basic information and so on. Therefore, for the general survey and identification of historical buildings, its goal is huge, the task is heavy, the degree of refinement is high, and the need for unified data storage standards is urgent.

1.2.3 There is a Serious Lack of Data Means to Deal with the Dynamic Protection and Management of Historical Buildings.

The current management methods of historical buildings can be divided into several aspects, such as general survey and identification, publication and listing of historical buildings, formulation of corresponding management measures for protection, and so on. However, according to the practice of various places, most of them have carried out the first two works well. In the management of historical buildings, there are some problems, such as the lack of technical support and the backwardness of dynamic monitoring management. As a result, it is difficult for the management department to grasp the real situation of the historical building dynamically and in real time, and the historical building is destroyed from time to time.

\section{RESEARCH PURPOSE AND TECHNICAL ROUTE}

\subsection{Research Purpose}

Geographic information system (GIS) is an important technology to acquire, process, manage and analyze geospatial data, which can also carry out secondary software development based on GIS (Sun, H.J., Zhang, Z.H., Liu. J., 2013). With the help of this technology, we can realize the digitization of spatial data of historical buildings, which is of great significance for the general survey and standardization of historical buildings. This paper analyzes the problems existing in the traditional methods of general survey and identification of historical buildings, and constructs the basic technical support of the general survey and identification of historical buildings from the aspects of general survey and identification standard system, investigation and data processing tool system, operation guidance system and so on, which is based on the technical requirements and the secondary development of GIS, taking the general survey and identification of historical buildings in Beijing as an example.

On the basis of the GIS, graphics, images, databases, mobile Internet and other information technologies, this paper carried 
out research on technical schemes for the general survey and identification of historical buildings, built a dictionary of historical building property data, and formed a complete database storage scheme for historical buildings (attribute data, spatial data, image data and other data). Research and develop the multi-source heterogeneous data management system, which can investigate and distinguish it in the early and late stages, and develop the mobile survey terminal based on the iPad system, so as to establish the integrated platform of early census data processing, field data collection, internal industry results integration, statistical results and planning map automatic output.

\subsection{Technical Route}

For the general survey and identification of historical buildings in specific areas, this paper proposes two "standard systems" -evaluation standard system and database standard system, two "application tools" -- survey tools on mobile terminal and data management tools on PC terminal, and an "operation manual" -user operation manual from the perspective of technical support.

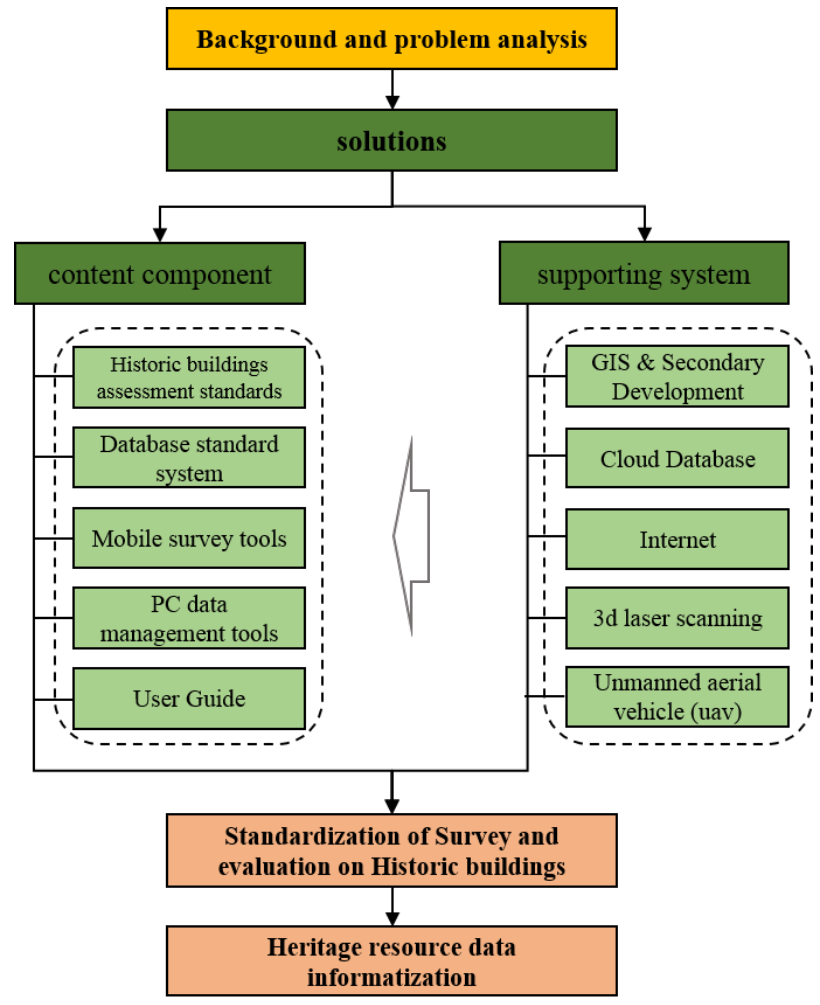

Figure1 Technology roadmap

\section{CONSTRUCTION OF INVESTIGATION AND IDENTIFICATION STANDARD AND TOOL SYSTEM OF HISTORIC BUILDINGS}

\subsection{Historical Building Evaluation Standard System}

For the "historical building evaluation standard system", this paper proposes a historical development process based on the general survey area, delineates the historical development zoning, summarizes the historical resource characteristics of the region. Finally, the working method of value evaluation standard and the grading evaluation standard of the historical building is formed. At the same time, this paper proposes a method of subdividing standards into different levels and forms quantitative indicators, so as to carry out quantitative evaluation later.

3.1.1 Research on Representative Historical Building Types in Different Periods Based on Historical Development Analysis

Through the combing of historical development themes, historical dynasties, and historical development sub-themes, this paper gradually clarifies the representative historical resources by using the analytic hierarchy process. In principle, buildings built more than 50 years can be recommended for inclusion, so buildings after the 1960s and 1970s are not included. Divide the urban construction of Beijing into different historical periods, find out the main clue of development, and carry out monographic study according to different historical periods for each clue. According to the development history of urban construction in Beijing, it is divided into six periods: Jin, Yuan, Ming, Qing, Republic of China and New China. The new China period was divided into the founding period, the comprehensive construction of socialism period and the cultural revolution period.

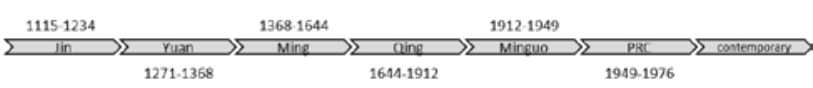

Figure2 The Age of Historical Development

The study of each historical period is conducted from the following six main lines of historical development, namely, business, culture, religion, military, residence and politics. For each main line, it carries out the secondary main line carding according to the specific characteristics of the historical period. For each historical period, it is located in space according to different historical development themes, and the historical stratification map is formed. For the historical buildings of the Jin Dynasty, the Yuan Dynasty and the Ming Dynasty, there are few historical relics because of their long history. There are many historical relics in the Qing Dynasty, the Republic of China and New China, so they are the focus of the general survey work. The overlapping map can clearly see the spatial distribution of historical information of the corresponding topics in each historical period, and provide architectural types and spatial guidance for the general survey of historical buildings.

Wang Fu of the Qing Dynasty, Yamen, the "Eight Banners" station, part of the business as well as schools, private gardens are mostly distributed in the inner city; clubhouses, cemeteries, private gardens, commerce and some schools are mostly distributed in the outer city. During the period of the Republic of China, a large number of construction was carried out, extending from the inner city to the outer city, especially in the Dashilan street, overbridge street and Chunshu street. During the period of New China, due to the influence of the long war, the finance was relatively tight and the construction was less.

\begin{tabular}{|c|c|c|c|c|c|}
\hline $\begin{array}{c}\text { Appare } \\
\text { nt } \\
\text { function }\end{array}$ & $\begin{array}{l}\text { Representativ } \\
\text { e building }\end{array}$ & Qing Dynasty & $\begin{array}{l}\text { Republic of } \\
\text { China period }\end{array}$ & $\begin{array}{l}\text { The early } \\
\text { days of } \\
\text { New China }\end{array}$ & $\begin{array}{l}\text { The initial } \\
\text { stage of } \\
\text { reform and } \\
\text { opening up }\end{array}$ \\
\hline \multirow{2}{*}{$\begin{array}{l}1 、 \\
\text { Political } \\
\text { categor } \\
\text { y }\end{array}$} & $\begin{array}{l}\text { Administrativ } \\
\text { e Yamen }\end{array}$ & $\begin{array}{l}\text { Administrative } \\
\text { Yamen }\end{array}$ & & & \\
\hline & $\begin{array}{l}\text { Administrative } \\
\text { organ }\end{array}$ & & $\begin{array}{c}\text { Administrativ } \\
\text { e organ }\end{array}$ & $\begin{array}{l}\text { Administra } \\
\text { tive organ }\end{array}$ & $\begin{array}{c}\text { Administra } \\
\text { tive organ }\end{array}$ \\
\hline \multirow{2}{*}{$\begin{array}{l}2 、 \\
\text { Military } \\
\text { categor } \\
\text { y }\end{array}$} & $\begin{array}{c}\text { Military } \\
\text { administration }\end{array}$ & $\begin{array}{c}\text { Military } \\
\text { administration }\end{array}$ & $\begin{array}{c}\text { Military } \\
\text { administration }\end{array}$ & $\begin{array}{c}\text { Military } \\
\text { administrat } \\
\text { ion } \\
\end{array}$ & $\begin{array}{c}\text { Military } \\
\text { administra } \\
\text { tion }\end{array}$ \\
\hline & $\begin{array}{l}\text { Military } \\
\text { Station }\end{array}$ & Military Station & & & \\
\hline 3 , & Market & Market & Market & Market & Market \\
\hline
\end{tabular}




\begin{tabular}{|c|c|c|c|c|c|}
\hline \multirow{5}{*}{$\begin{array}{l}\text { Busines } \\
\text { s } \\
\text { Adminis } \\
\text { tration }\end{array}$} & Store, shop & Store, shop & Store, shop & Store, shop & $\begin{array}{l}\text { Store, } \\
\text { shop }\end{array}$ \\
\hline & $\begin{array}{l}\text { Restaurant , } \\
\text { Accommodati } \\
\text { on }\end{array}$ & $\begin{array}{l}\text { Restaurant 、 } \\
\text { Accommodation }\end{array}$ & $\begin{array}{l}\text { Restaurant , } \\
\text { Accommodati } \\
\text { on }\end{array}$ & $\begin{array}{l}\text { Restaurant } \\
\text { Accommo } \\
\text { dation }\end{array}$ & $\begin{array}{c}\text { Restaurant } \\
\text { Accommo } \\
\text { dation }\end{array}$ \\
\hline & $\begin{array}{c}\begin{array}{c}\text { Financial } \\
\text { industry }\end{array} \\
\end{array}$ & $\begin{array}{c}\begin{array}{c}\text { Financial } \\
\text { industry }\end{array} \\
\end{array}$ & $\begin{array}{c}\begin{array}{c}\text { Financial } \\
\text { industry }\end{array} \\
\end{array}$ & $\begin{array}{l}\begin{array}{l}\text { Financial } \\
\text { industry }\end{array} \\
\end{array}$ & $\begin{array}{l}\begin{array}{l}\text { Financial } \\
\text { industry }\end{array} \\
\end{array}$ \\
\hline & $\begin{array}{l}\text { Industry, } \\
\text { handicrafts }\end{array}$ & $\begin{array}{l}\text { Industry, } \\
\text { handicrafts }\end{array}$ & $\begin{array}{l}\text { Industry, } \\
\text { handicrafts }\end{array}$ & $\begin{array}{c}\text { Industry, } \\
\text { handicrafts }\end{array}$ & $\begin{array}{c}\text { Industry, } \\
\text { handicrafts }\end{array}$ \\
\hline & $\begin{array}{l}\text { Entertainment } \\
\text { industry }\end{array}$ & $\begin{array}{l}\text { Entertainment } \\
\text { industry }\end{array}$ & $\begin{array}{c}\text { Entertainment } \\
\text { industry }\end{array}$ & $\begin{array}{c}\text { Entertainm } \\
\text { ent } \\
\text { industry } \\
\end{array}$ & $\begin{array}{c}\text { Entertainm } \\
\text { ent } \\
\text { industry } \\
\end{array}$ \\
\hline \multirow{5}{*}{$\begin{array}{l}\text { 4, } \\
\text { Religiou } \\
\text { s } \\
\text { categor } \\
\text { y }\end{array}$} & $\begin{array}{c}\text { Buddhist } \\
\text { architecture }\end{array}$ & $\begin{array}{c}\text { Buddhist } \\
\text { architecture }\end{array}$ & $\begin{array}{c}\text { Buddhist } \\
\text { architecture }\end{array}$ & & \\
\hline & $\begin{array}{c}\text { Christian } \\
\text { architecture }\end{array}$ & $\begin{array}{c}\text { Christian } \\
\text { architecture }\end{array}$ & $\begin{array}{c}\text { Christian } \\
\text { architecture }\end{array}$ & & \\
\hline & $\begin{array}{c}\text { Islamic } \\
\text { architecture }\end{array}$ & $\begin{array}{c}\text { Islamic } \\
\text { architecture }\end{array}$ & $\begin{array}{c}\text { Islamic } \\
\text { architecture }\end{array}$ & & \\
\hline & $\begin{array}{c}\text { Taoist } \\
\text { architecture }\end{array}$ & $\begin{array}{c}\text { Taoist } \\
\text { architecture }\end{array}$ & $\begin{array}{c}\text { Taoist } \\
\text { architecture }\end{array}$ & & \\
\hline & $\begin{array}{c}\text { Temple } \\
\text { ancestral hall }\end{array}$ & $\begin{array}{l}\text { Temple ancestral } \\
\text { hall }\end{array}$ & $\begin{array}{c}\text { Temple } \\
\text { ancestral hall }\end{array}$ & & \\
\hline \multirow{6}{*}{$\begin{array}{l}\text { 5, } \\
\text { Residen } \\
\text { tial } \\
\text { categor } \\
\text { y }\end{array}$} & $\begin{array}{l}\text { House } \\
\text { residence }\end{array}$ & House residence & $\begin{array}{c}\text { House } \\
\text { residence }\end{array}$ & & \\
\hline & $\begin{array}{l}\text { Old residence } \\
\text { of celebrities }\end{array}$ & $\begin{array}{l}\text { Old residence of } \\
\text { celebrities }\end{array}$ & $\begin{array}{l}\text { Old residence } \\
\text { of celebrities }\end{array}$ & $\begin{array}{c}\text { Old } \\
\text { residence } \\
\text { of } \\
\text { celebrities }\end{array}$ & $\begin{array}{c}\text { Old } \\
\text { residence } \\
\text { of } \\
\text { celebrities }\end{array}$ \\
\hline & Guild hall & Guild hall & Guild hall & & \\
\hline & $\begin{array}{c}\begin{array}{c}\text { Traditional } \\
\text { residence }\end{array} \\
\end{array}$ & $\begin{array}{c}\text { Traditional } \\
\text { residence }\end{array}$ & $\begin{array}{c}\text { Traditional } \\
\text { residence }\end{array}$ & & \\
\hline & $\begin{array}{l}\text { Modern } \\
\text { building }\end{array}$ & & $\begin{array}{l}\text { Modern } \\
\text { building }\end{array}$ & $\begin{array}{l}\text { Modern } \\
\text { building }\end{array}$ & $\begin{array}{l}\text { Modern } \\
\text { building }\end{array}$ \\
\hline & $\begin{array}{l}\text { Residential } \\
\text { district, } \\
\text { compound }\end{array}$ & & & & $\begin{array}{c}\text { Residential } \\
\text { district, } \\
\text { compound }\end{array}$ \\
\hline \multirow{7}{*}{$\begin{array}{l}\text { 6. } \\
\text { Public } \\
\text { facilities }\end{array}$} & $\begin{array}{l}\text { Educational } \\
\text { institutions }\end{array}$ & $\begin{array}{c}\text { Educational } \\
\text { institutions }\end{array}$ & $\begin{array}{l}\text { Educational } \\
\text { institutions }\end{array}$ & $\begin{array}{c}\text { Educationa } \\
\text { l } \\
\text { institutions } \\
\end{array}$ & $\begin{array}{c}\text { Education } \\
\text { al } \\
\text { institutions } \\
\end{array}$ \\
\hline & $\begin{array}{l}\text { Academic } \\
\text { institutions }\end{array}$ & & $\begin{array}{c}\text { Academic } \\
\text { institutions }\end{array}$ & $\begin{array}{c}\text { Academic } \\
\text { institutions }\end{array}$ & $\begin{array}{c}\text { Academic } \\
\text { institutions }\end{array}$ \\
\hline & $\begin{array}{l}\text { Cultural } \\
\text { facilities }\end{array}$ & & $\begin{array}{r}\text { Cultural } \\
\text { facilities }\end{array}$ & $\begin{array}{l}\text { Cultural } \\
\text { facilities }\end{array}$ & $\begin{array}{l}\text { Cultural } \\
\text { facilities }\end{array}$ \\
\hline & $\begin{array}{c}\text { Medical and } \\
\text { health } \\
\text { facilities } \\
\end{array}$ & $\begin{array}{c}\text { Medical and } \\
\text { health facilities }\end{array}$ & $\begin{array}{c}\text { Medical and } \\
\text { health } \\
\text { facilities }\end{array}$ & $\begin{array}{c}\text { Medical } \\
\text { and health } \\
\text { facilities }\end{array}$ & $\begin{array}{c}\text { Medical } \\
\text { and health } \\
\text { facilities }\end{array}$ \\
\hline & $\begin{array}{c}\text { Municipal } \\
\text { infrastructure }\end{array}$ & $\begin{array}{c}\text { Municipal } \\
\text { infrastructure }\end{array}$ & $\begin{array}{c}\text { Municipal } \\
\text { infrastructure }\end{array}$ & $\begin{array}{l}\text { Transporta } \\
\text { tion } \\
\text { facilities }\end{array}$ & $\begin{array}{l}\text { Transporta } \\
\text { tion } \\
\text { facilities }\end{array}$ \\
\hline & Garden & Garden & Garden & & \\
\hline & Green square & & Green square & $\begin{array}{c}\text { Green } \\
\text { square }\end{array}$ & $\begin{array}{l}\text { Green } \\
\text { square }\end{array}$ \\
\hline $\begin{array}{l}\text { 7v } \\
\text { Other }\end{array}$ & Other & Other & Other & Other & Other \\
\hline
\end{tabular}

Table 1. Induction table of historical building types

3.1.2 Evaluation and Subdivision Standard of Regional Historical Building value-taking Niujie Street as an Example

Take Niujie Street as an example to show the application of this method. The cultural collision of scholar culture, religious culture and folk culture in Niujie has formed the main historical and cultural characteristics of Niujie. Niujie is located in Xuannan area, where people of different regions and faiths live together. There are not only the religious culture dominated by Islam and Buddhism, but also the scholar culture formed by the literati who go to Beijing for the eaxm, as well as the unique folk culture formed by the integration of different nationalities. The collision of multiculturalism has created the cultural characteristics of Niujie Street today. Based on the above types of historical buildings, the existing representative buildings in Niujie area are mainly residential and religious, which are subdivided into clubhouse, traditional residence, Muslim architecture and Buddhist architecture.

\begin{tabular}{|c|c|c|c|c|c|}
\hline $\begin{array}{l}\mathrm{N} \\
\mathrm{o}\end{array}$ & $\begin{array}{l}\text { Architectural } \\
\text { function type }\end{array}$ & $\begin{array}{l}\text { Representative } \\
\text { building type }\end{array}$ & Characteristics & $\begin{array}{c}\text { Representa } \\
\text { tive } \\
\text { building } \\
\end{array}$ & Remarks \\
\hline \multirow[b]{2}{*}{1} & \multirow{2}{*}{$\begin{array}{c}\text { Residential } \\
\text { building }\end{array}$} & \multirow{2}{*}{ Clubhouse } & \multirow{2}{*}{$\begin{array}{l}\text { This is an important } \\
\text { carrier of Xuannan } \\
\text { scholar culture. A large } \\
\text { number of intellectuals } \\
\text { and famous businessmen }\end{array}$} & $\begin{array}{l}\text { Hunan } \\
\text { Guild Hall }\end{array}$ & $\begin{array}{c}\text { City } \\
\text { guarantee }\end{array}$ \\
\hline & & & & $\begin{array}{c}\text { Eastern } \\
\text { Guangdon } \\
\text { g Guild }\end{array}$ & Lost \\
\hline
\end{tabular}

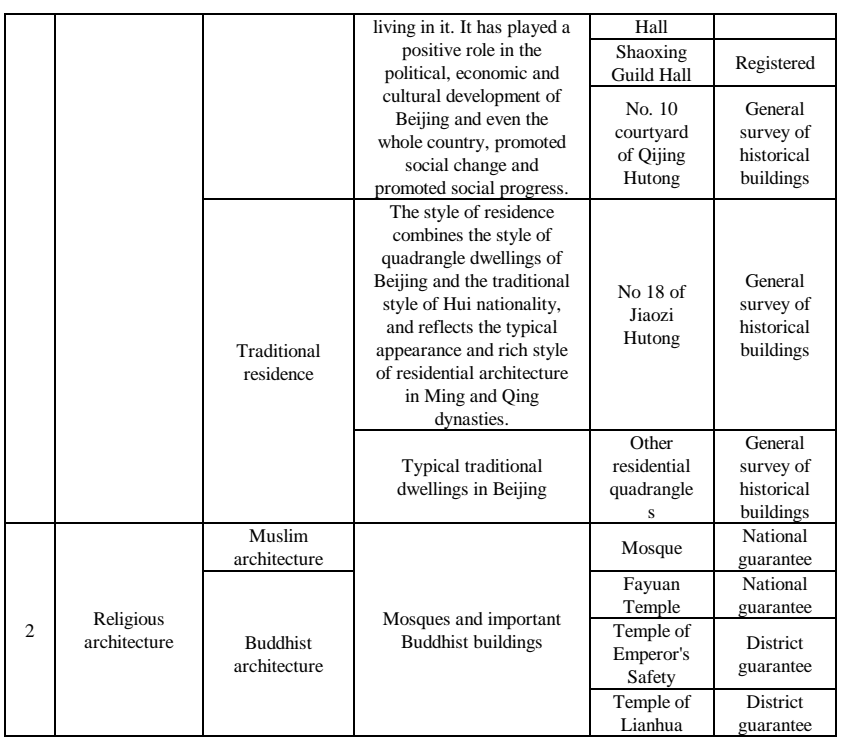

Table 2. Representative buildings in Niujie area

3.1.3 Standard for Evaluation of the Value of Single Historical Buildings

Taking the three major values of history, science and art as the first-class standard, and the basic standard put forward by the Ministry of Housing and Construction as the second-class standard, combined with the representative architectural characteristics of Niujie area, the subdivision standard of the value of historical architecture in this area is put forward and numbered to facilitate the construction of subsequent database.

\begin{tabular}{|c|c|c|c|c|c|}
\hline \multicolumn{2}{|c|}{$\begin{array}{l}\text { Primary } \\
\text { standard }\end{array}$} & \multicolumn{2}{|l|}{ Secondary standard } & Subdivision standard & $\begin{array}{l}\text { Standa } \\
\text { rd } \\
\text { code }\end{array}$ \\
\hline \multirow{9}{*}{$\begin{array}{c}\text { Hist } \\
\text { oric } \\
\text { al } \\
\text { and } \\
\text { cult } \\
\text { ural } \\
\text { valu } \\
\text { e }\end{array}$} & \multirow{9}{*}{1} & \multirow{5}{*}{$\begin{array}{l}\text { It reflects a certain } \\
\text { historical culture and } \\
\text { folk traditions, and has } \\
\text { specific characteristics } \\
\text { of the times and } \\
\text { regional characteristics. }\end{array}$} & \multirow{5}{*}{$1-1$} & $\begin{array}{l}\text { It reflects the characteristics of } \\
\text { courtyard architecture in Beijing in } \\
\text { the Qing Dynasty. }\end{array}$ & $1-1-1$ \\
\hline & & & & $\begin{array}{l}\text { It reflects the historical and } \\
\text { cultural and folk traditional } \\
\text { architectural characteristics of the } \\
\text { Hui nationality. }\end{array}$ & $1-1-2$ \\
\hline & & & & $\begin{array}{l}\text { It reflects the architectural artistic } \\
\text { characteristics of the clubhouse in } \\
\text { Beijing in the Qing Dynasty. }\end{array}$ & $1-1-3$ \\
\hline & & & & $\begin{array}{l}\text { It reflects the religious architecture } \\
\text { with the artistic characteristics of } \\
\text { Muslim religious architecture. }\end{array}$ & $1-1-4$ \\
\hline & & & & $\begin{array}{l}\text { It reflects the religious architecture } \\
\text { with the artistic characteristics of } \\
\text { Buddhist architecture. }\end{array}$ & $1-1-5$ \\
\hline & & $\begin{array}{l}\text { It is related to important } \\
\text { political, economic, } \\
\text { cultural, military and } \\
\text { other historical events } \\
\text { or famous figures. }\end{array}$ & $1-2$ & $\begin{array}{l}\text { Architecture related to the Reform } \\
\text { Movement of } 1898 \text { and related } \\
\text { historical figures. }\end{array}$ & $1-2-1$ \\
\hline & & $\begin{array}{c}\text { It has special } \\
\text { commemorative } \\
\text { significance in the } \\
\text { history of revolutionary } \\
\text { development. }\end{array}$ & $1-3$ & - & 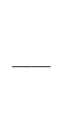 \\
\hline & & $\begin{array}{l}\text { A representative or } \\
\text { iconic building or the } \\
\text { representative work of a } \\
\text { famous architect. }\end{array}$ & $1-4$ & — & \\
\hline & & $\begin{array}{l}\text { Representative } \\
\text { workshops, shops, } \\
\text { factories and } \\
\text { warehouses in the } \\
\text { history of the } \\
\text { development of various } \\
\text { industries. }\end{array}$ & $1-5$ & - & 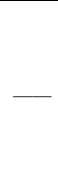 \\
\hline
\end{tabular}




\begin{tabular}{|c|c|c|c|c|c|}
\hline \multirow{5}{*}{$\begin{array}{c}\text { Scie } \\
\text { ntifi } \\
\text { c } \\
\text { valu } \\
\text { e }\end{array}$} & \multirow{5}{*}{2} & \multirow{4}{*}{$\begin{array}{l}\text { Styles, structures, } \\
\text { materials, construction } \\
\text { techniques or } \\
\text { engineering techniques } \\
\text { can reflect regional and } \\
\text { artistic characteristics } \\
\text { or have scientific } \\
\text { research value. }\end{array}$} & \multirow{4}{*}{$2-1$} & $\begin{array}{c}\text { It reflects the artistic } \\
\text { characteristics of the combination } \\
\text { of construction technology of Han } \\
\text { nationality and Hui nationality. }\end{array}$ & $2-1-1$ \\
\hline & & & & $\begin{array}{l}\text { It reflects the engineering and } \\
\text { technical level of residential } \\
\text { buildings in the Qing Dynasty. }\end{array}$ & $2-1-2$ \\
\hline & & & & $\begin{array}{l}\text { It reflects the structural } \\
\text { characteristics of residential } \\
\text { buildings in the Qing Dynasty. }\end{array}$ & $2-1-3$ \\
\hline & & & & $\begin{array}{l}\text { It reflects the characteristics of } \\
\text { architectural structure in the } \\
\text { period of the Republic of China. }\end{array}$ & $2-1-4$ \\
\hline & & $\begin{array}{l}\text { The combination of } \\
\text { architectural forms or } \\
\text { the spatial layout is } \\
\text { advanced in a certain } \\
\text { period of time. }\end{array}$ & $2-2$ & $\begin{array}{l}\text { It reflects the spatial layout } \\
\text { characteristics of courtyard } \\
\text { architecture in Qing Dynasty. }\end{array}$ & $2-2-1$ \\
\hline \multirow{8}{*}{$\begin{array}{c}\text { Arti } \\
\text { stic } \\
\text { valu } \\
\text { e }\end{array}$} & \multirow{8}{*}{3} & \multirow{2}{*}{$\begin{array}{l}\text { Architectural space, } \\
\text { modeling, color, details } \\
\text { and decoration have } \\
\text { certain artistic } \\
\text { characteristics and } \\
\text { value. }\end{array}$} & \multirow{2}{*}{ 3-1 } & $\begin{array}{l}\text { It reflects the artistic features of } \\
\text { the architectural details pattern of } \\
\text { the Qing Dynasty. }\end{array}$ & $3-1-1$ \\
\hline & & & & $\begin{array}{l}\text { It reflects the artistic } \\
\text { characteristics of literati class } \\
\text { architecture in Qing Dynasty. }\end{array}$ & $3-1-2$ \\
\hline & & \multirow{3}{*}{$\begin{array}{l}\text { It is iconic or symbolic } \\
\text { in a certain area of the } \\
\text { city or countryside, and } \\
\text { has a sense of group } \\
\text { psychological identity. }\end{array}$} & \multirow{3}{*}{$3-2$} & The iconic Muslim building & $3-2-1$ \\
\hline & & & & Iconic Buddhist buildings & $3-2-2$ \\
\hline & & & & $\begin{array}{l}\text { Iconic Hui Folk Residential } \\
\text { Buildings }\end{array}$ & $3-2-3$ \\
\hline & & \multirow{3}{*}{$\begin{array}{l}\text { It reflects the artistic } \\
\text { characteristics of a } \\
\text { certain region or nation. }\end{array}$} & \multirow{3}{*}{ 3-3 } & $\begin{array}{c}\text { It reflects the artistic } \\
\text { characteristics of residential } \\
\text { architecture in Beijing in the Qing } \\
\text { Dynasty. }\end{array}$ & $3-3-1$ \\
\hline & & & & $\begin{array}{l}\text { It reflects the artistic } \\
\text { characteristics of the integration of } \\
\text { northern and Jiangnan } \\
\text { architectural styles. }\end{array}$ & $3-3-2$ \\
\hline & & & & $\begin{array}{c}\text { It reflects the artistic } \\
\text { characteristics of Hui architecture. }\end{array}$ & $3-3-3$ \\
\hline
\end{tabular}

Table 3. Standard Table for value Segmentation of Historical buildings in Niujie area

This paper studies each historical building from the aspects of natural and human environment, architectural characteristics and preservation, historical evolution, etc., combs its value characteristic, and score the corresponding value items. In addition, this paper puts forward the protection and utilization management measures. Finally, Finally, the overall value of historical buildings is summarized based on the above contents.

\begin{tabular}{|c|c|c|c|c|}
\hline 1 & $\begin{array}{c}\text { Main } \\
\text { contents }\end{array}$ & \multicolumn{2}{|c|}{ Basic content } & Remarks \\
\hline 2 & $\begin{array}{l}\text { Geographi } \\
\quad \text { cal } \\
\text { location }\end{array}$ & \multicolumn{2}{|c|}{$\begin{array}{l}\text { The building complex is located in the middle of Niujie } \\
\text { Street Historical and Cultural District, No. } 18 \text { Jiaozi Hutong, } \\
\text { Xicheng District, Beijing. }\end{array}$} & $\begin{array}{l}\text { Street、 } \\
\text { number } \\
\text { plate、area }\end{array}$ \\
\hline 3 & $\begin{array}{l}\text { Natural } \\
\text { and } \\
\text { human } \\
\text { environme } \\
\text { nt }\end{array}$ & \multicolumn{2}{|c|}{$\begin{array}{l}\text { The building complex is located in the Jiaozi hutong, the } \\
\text { central and western side of the original hutong during the } \\
\text { Kangxi period built a mosque, called Yongshou Temple, and } \\
\text { then changed to the location of Beijing Civil Affairs Daily } \\
\text { Chemical Industry Company. No. 31, Jiaozi Hutong is the } \\
\text { former Gansu clubhouse. }\end{array}$} & Overview \\
\hline 4 & $\begin{array}{c}\text { Basic } \\
\text { situation } \\
\text { of } \\
\text { architectu } \\
\text { re }\end{array}$ & \multicolumn{2}{|c|}{$\begin{array}{l}\text { No. } 18 \text { courtyard building sitting west headed east, two } \\
\text { into the courtyard, single layer courtyard layout. }\end{array}$} & Overview \\
\hline 5 & $\begin{array}{c}\text { Preservati } \\
\text { on status } \\
\text { of } \\
\text { Historical } \\
\text { buildings }\end{array}$ & $\begin{array}{l}\text { The whole } \\
\text { Historical } \\
\text { form and the } \\
\text { Preservation } \\
\text { of Historical } \\
\text { pattern of } \\
\text { Historical } \\
\text { Architecture }\end{array}$ & $\begin{array}{l}\text { The shape of the whole building is } \\
\text { well preserved, the structure is firm and } \\
\text { stable, and the internal pattern is complete. }\end{array}$ & $\begin{array}{c}\text { Courtyard } \\
\text { pattern }\end{array}$ \\
\hline
\end{tabular}

\begin{tabular}{|c|c|c|c|c|c|}
\hline & & \multicolumn{2}{|c|}{$\begin{array}{l}\text { Preservation } \\
\text { status of } \\
\text { single } \\
\text { Historical } \\
\text { Building }\end{array}$} & $\begin{array}{l}\text { The lifting beam structure, stylobate } \\
\text { and wall of the main room are well } \\
\text { preserved, the roof tiles are complete, the } \\
\text { roof ridges are well preserved, and the } \\
\text { scorpion tail is missing. The wooden lattice } \\
\text { bars of doors and windows are well } \\
\text { preserved, the patterns are exquisite, and } \\
\text { the Soviet-style color paintings are kept } \\
\text { intact. Except for one reconstruction, the } \\
\text { main structure of the wing-room is very } \\
\text { complete, the platform foundation and wall } \\
\text { are well preserved, some of the roof tiles } \\
\text { are damaged and missing, and the tile } \\
\text { pattern is exquisite. The wooden lattice } \\
\text { bars of doors and windows are well } \\
\text { preserved, and the pattern is roughly the } \\
\text { same as that of the main room.The main } \\
\text { structure of the courtyard door is preserved } \\
\text { completely, the stylobate is worn out, and } \\
\text { the roof and roof ridge are well preserve. } \\
\text { The details of the wall are beautifully } \\
\text { carved, and the decorative design of Arabic } \\
\text { calligraphy combines the style of the Han } \\
\text { nationality and the Hui nationality. The } \\
\text { pattern design of Wadang, drum stone and } \\
\text { decorative cylinder is typical Han style } \\
\text { pattern, which is beautifully decorated, but } \\
\text { one decorative cylinder is damaged. }\end{array}$ & $\begin{array}{c}\text { Historical } \\
\text { components: } \\
\text { 1. Structural } \\
\text { members } \\
\text { (main load- } \\
\text { bearing } \\
\text { structure, } \\
\text { stylobate, } \\
\text { wall, roof, } \\
\text { roof ridge) } \\
2 . \\
\text { Decorative } \\
\text { and } \\
\text { structural } \\
\text { components } \\
\text { (doors, } \\
\text { windows, } \\
\text { carvings, } \\
\text { color } \\
\text { paintings, } \\
\text { shadow } \\
\text { walls, oil } \\
\text { ornaments) }\end{array}$ \\
\hline & & \multicolumn{2}{|c|}{$\begin{array}{l}\text { Preservation } \\
\text { status of the } \\
\text { Historical } \\
\text { Environment } \\
\text { of the } \\
\text { Courtyard }\end{array}$} & $\begin{array}{l}\text { The middle old trees still exist in the } \\
\text { courtyard, and the floor of the courtyard is } \\
\text { brightly colored and has Islamic style. }\end{array}$ & $\begin{array}{l}\text { Ancient } \\
\text { trees, } \\
\text { traditional } \\
\text { pavements, } \\
\text { yard , etc. }\end{array}$ \\
\hline 6 & $\begin{array}{l}\text { Historical } \\
\text { evolution }\end{array}$ & \multicolumn{3}{|c|}{$\begin{array}{l}\text { The building was built in the Republic of China and was } \\
\text { used as a residence in history. }\end{array}$} & $\begin{array}{c}\text { Contains } \\
\text { information } \\
\text { about the } \\
\text { date of } \\
\text { construction, } \\
\text { historical } \\
\text { functions, } \\
\text { and so on at } \\
\text { least. }\end{array}$ \\
\hline 7 & $\begin{array}{c}\text { Value } \\
\text { evaluation }\end{array}$ & \multicolumn{3}{|c|}{$\begin{array}{l}\text { The courtyard reflects the history, culture and folk } \\
\text { traditions of the Hui nationality, has the characteristics of } \\
\text { Gaoniu Street area, and has a certain historical and cultural } \\
\text { value. The structure and materials of the building reflect the } \\
\text { technical level of the residential building, and its construction } \\
\text { technology reflects the artistic characteristics of the Han } \\
\text { nationality and the Hui nationality. The layout of the } \\
\text { courtyard reflects the characteristics of courtyard } \\
\text { architecture in Beijing, and has a certain scientific value. The } \\
\text { courtyard reflects the typical design style of the integration of } \\
\text { Han and Hui architecture. The architectural patterns such as } \\
\text { brick carving, stone carving, color painting and partition fan } \\
\text { have the artistic characteristics of the Qing Dynasty, have } \\
\text { certain landmarks in Niujie area, and can bring Niujie } \\
\text { residents a certain sense of group psychological identity, } \\
\text { which reflects the artistic characteristics of Hui nationality in } \\
\text { Niujie area and has high artistic value. }\end{array}$} & $\begin{array}{l}\text { Corresponds } \\
\text { to } 2 \text { to } 6 \\
\text { items.Corres } \\
\text { ponds to } 9 \\
\text { items } \\
\text { (standards) }\end{array}$ \\
\hline 8 & $\begin{array}{c}\text { Value } \\
\text { keywords }\end{array}$ & \multicolumn{3}{|c|}{$\begin{array}{l}\text { It reflects the history, culture and folk traditions of the } \\
\text { Hui nationality. The construction technology reflects the } \\
\text { artistic characteristics of the Han nationality and the Hui } \\
\text { nationality. This is a typical design style integrated Han and } \\
\text { Hui architectural. The pattern has the artistic characteristics } \\
\text { of the Qing Dynasty; }\end{array}$} & $\begin{array}{l}\text { Standardized } \\
\text { extraction of } \\
7 \text { items }\end{array}$ \\
\hline \multirow{8}{*}{9} & & 3 & & $\begin{array}{l}\text { It reflects a certain historical culture and folk } \\
\text { ditions, and has specific characteristics of the } \\
\text { times and regional characteristics. }\end{array}$ & \multirow{5}{*}{$\begin{array}{l}\text { Historical } \\
\text { and cultural } \\
\text { value }\end{array}$} \\
\hline & & 0 & & $\begin{array}{l}\text { Related to important political, economic, } \\
\text { Itural, military and other historical events or } \\
\text { famous figures. }\end{array}$ & \\
\hline & & 0 & & $\begin{array}{l}\text { It has special commemorative significance in } \\
\text { the history of revolutionary development. }\end{array}$ & \\
\hline & & 0 & & $\begin{array}{l}\text { A representative or iconic building or the } \\
\text { representative work of a famous architect. }\end{array}$ & \\
\hline & & 0 & & $\begin{array}{l}\text { Representative workshops, shops, factories } \\
\text { I warehouses in the history of the development } \\
\text { of various industries. }\end{array}$ & \\
\hline & & 3 & & $\begin{array}{l}\text { Styles, structures, materials, construction } \\
\text { hniques or engineering techniques can reflect } \\
\text { regional and artistic characteristics or have } \\
\text { scientific research value. }\end{array}$ & \multirow{2}{*}{$\begin{array}{l}\text { Scientific } \\
\text { value }\end{array}$} \\
\hline & & 1 & & $\begin{array}{l}\text { The combination of architectural forms or the } \\
\text { atial layout is advanced in a certain period of } \\
\text { time. }\end{array}$ & \\
\hline & & & & & \\
\hline
\end{tabular}




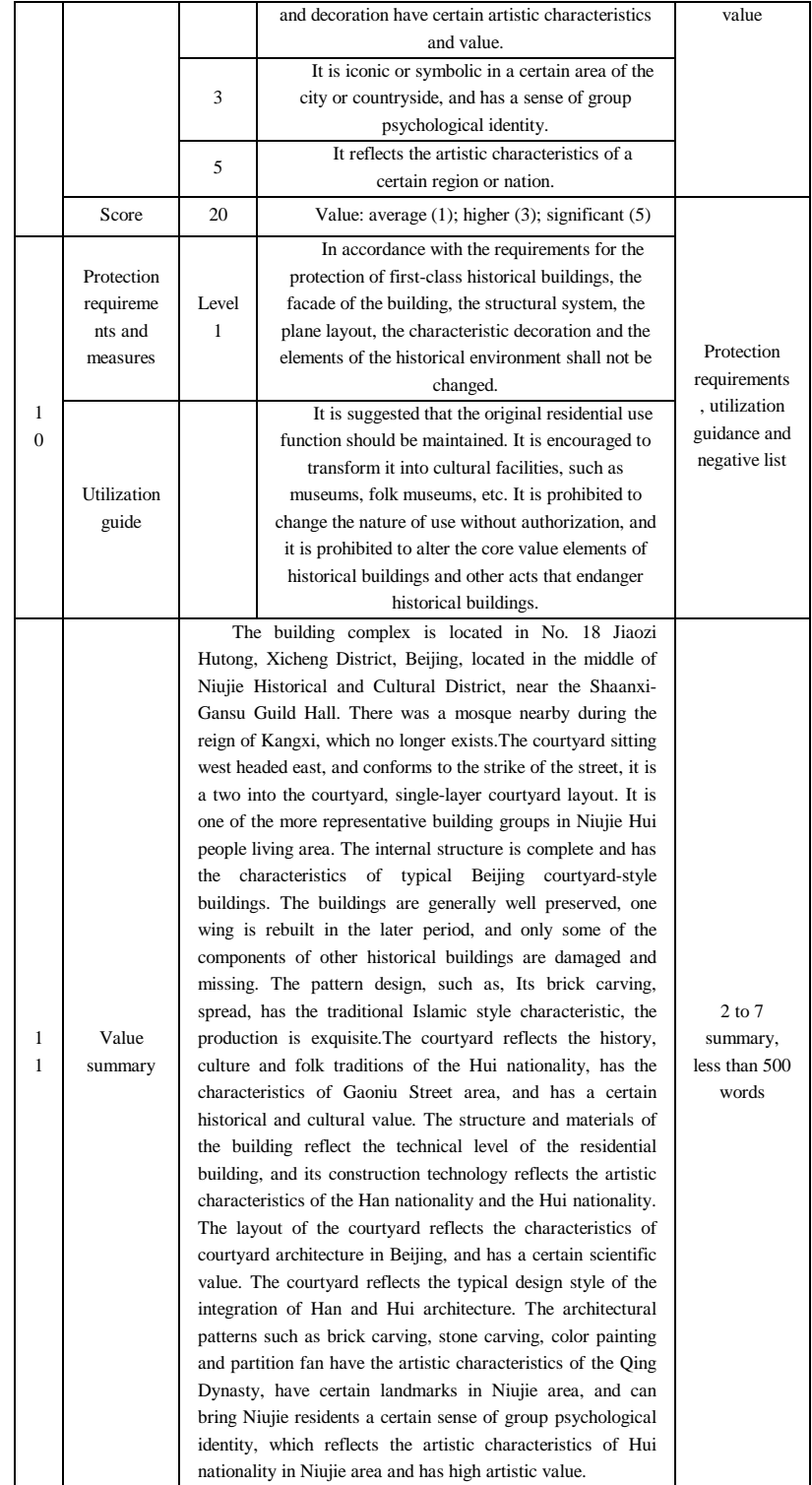

Table 4. Historical building value evaluation form

Each historical building in Niujie Street is evaluated and scored by using the above methods, and the grade of historical building is evaluated according to the score.

\begin{tabular}{|c|c|c|c|c|}
\hline No. & $\begin{array}{l}\text { Historical } \\
\text { remains }\end{array}$ & $\begin{array}{l}\text { Corresponding } \\
\text { subdivision value } \\
\text { standard } \\
\end{array}$ & $\begin{array}{l}\text { Intact } \\
\text { degree }\end{array}$ & $\begin{array}{c}\begin{array}{c}\text { Level of } \\
\text { protection } \\
\text { (recommended) }\end{array} \\
\end{array}$ \\
\hline $\begin{array}{c}\text { BJ_XC_NJ_0 } \\
002\end{array}$ & $\begin{array}{c}\text { No. 18, } \\
\text { Jiaozi } \\
\text { Hutong }\end{array}$ & $\begin{array}{l}1-1-1 、 1-1-2 、 2-1-1 、 \\
2-1-2 、 3-2-3 、 3-3-3\end{array}$ & $\begin{array}{c}\text { The whole } \\
\text { is well } \\
\text { preserved. }\end{array}$ & Level 1 \\
\hline $\begin{array}{c}\text { BJ_XC_NJ_0 } \\
007\end{array}$ & $\begin{array}{l}\text { No.10 } \\
\text { Qijing } \\
\text { Hutong }\end{array}$ & $\begin{array}{l}1-1-1,1-1-3 、 2-1-2, \\
2-1-3,2-2-1 、 3-1-1, \\
3-1-2,3-3-1,3-3-2\end{array}$ & $\begin{array}{c}\text { The whole } \\
\text { is well } \\
\text { preserved. }\end{array}$ & Level 1 \\
\hline $\begin{array}{c}\text { BJ_XC_NJ_0 } \\
008\end{array}$ & $\begin{array}{l}\text { No.19 } \\
\text { Qijing } \\
\text { Hutong }\end{array}$ & $\begin{array}{c}1-1-1 、 2-1-2 、 2-1-3 、 \\
2-1-4\end{array}$ & $\begin{array}{c}\text { The main } \\
\text { parts are } \\
\text { well } \\
\text { preserved. }\end{array}$ & Level 2 \\
\hline $\begin{array}{c}\text { BJ_XC_NJ_0 } \\
005\end{array}$ & $\begin{array}{c}\text { No } 25 \text { Back } \\
\text { street of } \\
\text { Fayuan } \\
\text { Temple }\end{array}$ & $1-1-1,2-1-2 、 3-3-1$ & $\begin{array}{c}\text { The main } \\
\text { parts are } \\
\text { well } \\
\text { preserved. }\end{array}$ & Level 2 \\
\hline $\begin{array}{c}\text { BJ_XC_NJ_0 } \\
006\end{array}$ & $\begin{array}{c}\text { No.5 Qijing } \\
\text { Hutong }\end{array}$ & $2-1-2 、 3-3-1$ & $\begin{array}{c}\text { Part of it } \\
\text { is well } \\
\text { preserved. }\end{array}$ & Level 3 \\
\hline $\begin{array}{c}\text { BJ_XC_NJ_0 } \\
004\end{array}$ & $\begin{array}{c}\text { No } 11 \\
\text { Back street } \\
\text { of Fayuan } \\
\text { Temple }\end{array}$ & $1-1-1,2-1-2 、 3-3-1$ & $\begin{array}{l}\text { Part of it } \\
\text { is well } \\
\text { preserved. }\end{array}$ & Level 3 \\
\hline
\end{tabular}

\begin{tabular}{|c|c|c|c|c|}
\hline $\begin{array}{c}\text { BJ_XC_NJ_0 } \\
003\end{array}$ & $\begin{array}{c}\text { No } 9 \\
\text { Back street } \\
\text { of Fayuan } \\
\text { Temple }\end{array}$ & $1-1-1,2-1-2 、 3-3-1$ & $\begin{array}{l}\text { Part of it } \\
\text { is well } \\
\text { preserved. }\end{array}$ & Level 3 \\
\hline $\begin{array}{c}\text { BJ_XC_NJ_0 } \\
001\end{array}$ & $\begin{array}{r}\text { No. } \\
\text { 16, Jiaozi } \\
\text { Hutong }\end{array}$ & $1-1-1,2-1-2$ & $\begin{array}{l}\text { Part of it } \\
\text { is well } \\
\text { preserved. }\end{array}$ & Level 3 \\
\hline $\begin{array}{c}\text { BJ_XC_NJ_0 } \\
009\end{array}$ & $\begin{array}{l}\quad \text { No.2 } \\
3 \text { Qijing } \\
\text { Hutong }\end{array}$ & $1-1-1 、 2-1-2$ & $\begin{array}{l}\text { Part of it } \\
\text { is well } \\
\text { preserved. }\end{array}$ & Level 3 \\
\hline $\begin{array}{c}\text { BJ_XC_NJ_0 } \\
0012\end{array}$ & $\begin{array}{c}\text { No.3 } \\
\text { 9 West } \\
\text { Street of } \\
\text { South Heng }\end{array}$ & $2-1-2$ & $\begin{array}{l}\text { Part of it } \\
\text { is well } \\
\text { preserved. }\end{array}$ & Level 3 \\
\hline
\end{tabular}

Table 5. Historical building protection classification evaluation form of Niujie street

\subsection{Database Standard System--- Geo-Spatial Database of Historical buildings based on GIS}

For the "database standard system", this paper puts forward the database structure which covers the historical building ontology, the characteristic part, the historical environment element, the protection scope, the construction control zone, the historical building photo and the three-dimensional scanning model. Each kind of spatial element corresponds to the standardized attribute field and records the corresponding attribute, and the nonspatial information corresponds to the standardized coding format to facilitate the association of information.

The special geo-spatial database of historical architecture is established, the geographical coordinates are based on the local coordinates of Beijing, and the database is stored in ESRI File Geodatabase format. The database is composed of seven layers, which are historical building Noumenon, architectural value location, courtyard or unit boundary, historical environmental elements, protection scope and construction control zone.

\begin{tabular}{|c|c|c|c|}
\hline Layer & Name & Feature types & \\
\hline \multirow{2}{*}{$\begin{array}{l}\text { Architectu } \\
\text { re }\end{array}$} & LSJZ_M & Polygon & Planar historical building \\
\hline & LSJZ_X & Polyline & Linear historical building \\
\hline $\begin{array}{c}\text { Building } \\
\text { value } \\
\text { position }\end{array}$ & JZBW & Point & $\begin{array}{l}\text { The main facade, plane layout, characteristic } \\
\text { parts, materials, structure, decoration and so on. }\end{array}$ \\
\hline $\begin{array}{l}\text { Courtyard } \\
\text { / parcel } \\
\text { boundary }\end{array}$ & YLDK & Polygon & $\begin{array}{l}\text { The principle is that the house number } \\
\text { corresponds to the boundary of the courtyard. } \\
\text { Special circumstances require special treatment. }\end{array}$ \\
\hline $\begin{array}{l}\text { Historical } \\
\text { environme } \\
\text { ntal } \\
\text { elements }\end{array}$ & HJYS & Point & $\begin{array}{l}\text { A part of the environment that plays an important } \\
\text { role in the formation of historical architectural } \\
\text { features, such as trees, water bodies, topography, } \\
\text { landscape, etc. }\end{array}$ \\
\hline $\begin{array}{c}\text { Protection } \\
\text { range }\end{array}$ & BHFW & Polygon & $\begin{array}{l}\text { Historic buildings and necessary coordination } \\
\text { areas of style and features. }\end{array}$ \\
\hline $\begin{array}{l}\text { Constructi } \\
\text { on control } \\
\text { zone }\end{array}$ & JKDD & Polygon & $\begin{array}{l}\text { For historic neighborhoods and style and features } \\
\text { areas, the surrounding environment may face } \\
\text { drastic changes in the area. }\end{array}$ \\
\hline
\end{tabular}

Table 6. Elements of class division standard table

Each of the above elements (layers) corresponds to standardized attribute fields and has specified input rules. The rule contains the field name, type, alias, whether null values are allowed, field length, fill requirements, and so on. The following table takes the historical building ontology layer as an example to show the input format of standardized data. Of course, each layer corresponds to a different input standard. Due to space constraints, we do not list them here.

\begin{tabular}{|c|c|c|c|c|c|c|}
\hline \multicolumn{3}{|c|}{ FeatureClassName } & \multicolumn{4}{|c|}{ LSJZ_M } \\
\hline \multicolumn{3}{|c|}{ FeatureClassAlias } & \multicolumn{4}{|c|}{ Historic building } \\
\hline \multicolumn{3}{|c|}{ FeatureClassType } & \multicolumn{4}{|c|}{$\begin{array}{l}\text { Polygon Features } \\
\end{array}$} \\
\hline \multicolumn{3}{|c|}{ CoordinateSystem } & \multicolumn{4}{|c|}{ Beijing local coordinates } \\
\hline \multicolumn{7}{|c|}{ Fields } \\
\hline $\begin{array}{c}\text { FieldNa } \\
\text { me }\end{array}$ & $\begin{array}{c}\text { Dat } \\
\text { aTy } \\
\text { pe }\end{array}$ & Alias & $\begin{array}{l}\text { Allo } \\
\text { wNu } \\
\text { llVa } \\
\text { lues }\end{array}$ & $\begin{array}{l}\text { Def } \\
\text { ault } \\
\text { Val } \\
\text { ue }\end{array}$ & $\begin{array}{l}\text { Len } \\
\text { gth }\end{array}$ & Comments \\
\hline $\begin{array}{c}\text { DDJZX } \\
\mathrm{H}\end{array}$ & $\begin{array}{l}\mathrm{VA} \\
\mathrm{RC} \\
\mathrm{HA}\end{array}$ & $\begin{array}{c}\text { Serial } \\
\text { number of } \\
\text { a single }\end{array}$ & $\begin{array}{l}\text { not } \\
\text { null }\end{array}$ & & 32 & $\begin{array}{l}\text { Provincial__ municipal_ _ district } \\
\text { and county street _ serial } \\
\text { number_building serial number, }\end{array}$ \\
\hline
\end{tabular}




\begin{tabular}{|c|c|c|c|c|c|}
\hline & $\mathrm{R} 2$ & building & & & such as:BJ_DC_QM_0001_01 \\
\hline $\begin{array}{l}\text { DDJZ } \\
\text { MC }\end{array}$ & $\begin{array}{l}\text { VA } \\
\text { RC } \\
\text { HA } \\
\text { R2 }\end{array}$ & $\begin{array}{l}\text { Name of a } \\
\text { single } \\
\text { building }\end{array}$ & $\begin{array}{l}\text { not } \\
\text { null }\end{array}$ & 500 & $\begin{array}{l}\text { Quadrangles include: main room, } \\
\text { reversely-set house, east wing } \\
\text { room, west wing room, side room, } \\
\text { house door, backside room, etc. }\end{array}$ \\
\hline JZLB & $\begin{array}{l}\text { VA } \\
\text { RC } \\
\text { HA } \\
\text { R2 }\end{array}$ & $\begin{array}{l}\text { Building } \\
\text { category }\end{array}$ & $\begin{array}{l}\text { not } \\
\text { null }\end{array}$ & 32 & $\begin{array}{l}\text { (0) Cultural relics. } \\
\text { (1) Historical buildings. } \\
\text { (2) Proposed historic buildings. } \\
\text { (3) Traditional style architecture. } \\
\text { (4) Buildings in harmony with } \\
\text { traditional styles and features. } \\
\text { (5) Buildings that are not in } \\
\text { harmony with the traditional style } \\
\text { and features. }\end{array}$ \\
\hline $\begin{array}{l}\text { bdr_are } \\
\text { a }\end{array}$ & $\begin{array}{c}\mathrm{FL} \\
\mathrm{OA} \\
\mathrm{T}\end{array}$ & $\begin{array}{l}\text { Built-up } \\
\text { area }\end{array}$ & $\begin{array}{l}\text { not } \\
\text { null }\end{array}$ & & $\begin{array}{l}\text { Statistics of total building area. } \\
\text { Unit: square meters }\end{array}$ \\
\hline $\begin{array}{l}\text { bdr_co } \\
\text { vered_a } \\
\text { rea }\end{array}$ & $\begin{array}{l}\text { INT } \\
\text { EG } \\
\text { ER } \\
\end{array}$ & $\begin{array}{c}\text { Area } \\
\text { covered }\end{array}$ & $\begin{array}{l}\text { not } \\
\text { null }\end{array}$ & & $\begin{array}{l}\text { Statistics of building base area. } \\
\text { Unit: square meters }\end{array}$ \\
\hline $\begin{array}{c}\text { bdr_ag } \\
\text { e }\end{array}$ & $\begin{array}{l}\text { INT } \\
\text { EG } \\
\text { ER }\end{array}$ & $\begin{array}{l}\text { Architectur } \\
\text { al Age }\end{array}$ & $\begin{array}{l}\text { not } \\
\text { null }\end{array}$ & & $\begin{array}{l}\text { Fill in the number code: } \\
\text { (0) Ming (1368-1644) and before } \\
\text { (1) Qing Dynasty (1644-1911) } \\
\text { (2) Republic of China (1911- } \\
\text { 1949) } \\
\text { (3) 1949-1979 } \\
\text { (4) After 1980 }\end{array}$ \\
\hline $\begin{array}{l}\text { bdr_str } \\
\text { uct }\end{array}$ & $\begin{array}{l}\text { INT } \\
\text { EG } \\
\text { ER }\end{array}$ & $\begin{array}{l}\text { Building } \\
\text { structure }\end{array}$ & & & $\begin{array}{l}\text { (0) Wood structure; } \\
\text { (1) Brick and wood structure; } \\
\text { (2) Brick-concrete structure; } \\
\text { (3) steel-concrete structure; } \\
\text { (4) Other structures. }\end{array}$ \\
\hline $\begin{array}{l}\text { bdr_hei } \\
\text { ght }\end{array}$ & $\begin{array}{c}\mathrm{FL} \\
\mathrm{OA} \\
\mathrm{T}\end{array}$ & $\begin{array}{l}\text { Building } \\
\text { height }\end{array}$ & $\begin{array}{l}\text { not } \\
\text { null }\end{array}$ & & $\begin{array}{l}\text { Fill in according to the number of } \\
\text { main floors of the building. Unit: } \\
\text { layer. }\end{array}$ \\
\hline $\begin{array}{l}\text { bdr_qu } \\
\text { ality }\end{array}$ & $\begin{array}{l}\text { INT } \\
\text { EG } \\
\text { ER }\end{array}$ & $\begin{array}{l}\text { Building } \\
\text { quality }\end{array}$ & & & $\begin{array}{l}\text { (0)Good: the structure and } \\
\text { enclosure materials are in good } \\
\text { condition; } \\
\text { (1) Medium: the structure is } \\
\text { stable and the enclosure material } \\
\text { is locally damaged; } \\
\text { (2) Poor: the structure is seriously } \\
\text { damaged and the enclosure } \\
\text { material is missing. }\end{array}$ \\
\hline $\mathrm{m}$ & $\begin{array}{l}\text { INT } \\
\text { EG } \\
\text { ER }\end{array}$ & $\begin{array}{l}\text { Property } \\
\text { right } \\
\text { nature of } \\
\text { current } \\
\text { situation } \\
\end{array}$ & & & $\begin{array}{l}\text { (0) Unit property; } \\
\text { (1) Public property; } \\
\text { (2) Private property; } \\
\text { (999999) Other }\end{array}$ \\
\hline $\begin{array}{l}\text { bdr_pro } \\
\text { perty_ri } \\
\text { ght_oth } \\
\text { er }\end{array}$ & $\begin{array}{l}\text { VA } \\
\text { RC } \\
\text { HA } \\
\text { R2 }\end{array}$ & $\begin{array}{l}\text { Property } \\
\text { right } \\
\text { nature of } \\
\text { current } \\
\text { situation(ot } \\
\text { hers) }\end{array}$ & & 500 & $\begin{array}{l}\text { Indicate the nature of the property } \\
\text { rights of the specific status quo. }\end{array}$ \\
\hline $\begin{array}{l}\text { bdr_is_ } \\
\text { start_re } \\
\text { pair }\end{array}$ & $\begin{array}{l}\text { INT } \\
\text { EG } \\
\text { ER }\end{array}$ & $\begin{array}{l}\text { Whether } \\
\text { repairs } \\
\text { have been } \\
\text { carried out }\end{array}$ & & & $\begin{array}{l}\text { (0) Repair; } \\
\text { (1) Not repaired. }\end{array}$ \\
\hline
\end{tabular}

Table 7 Element class attribute structure

\subsection{Mobile Terminal Research Tool}

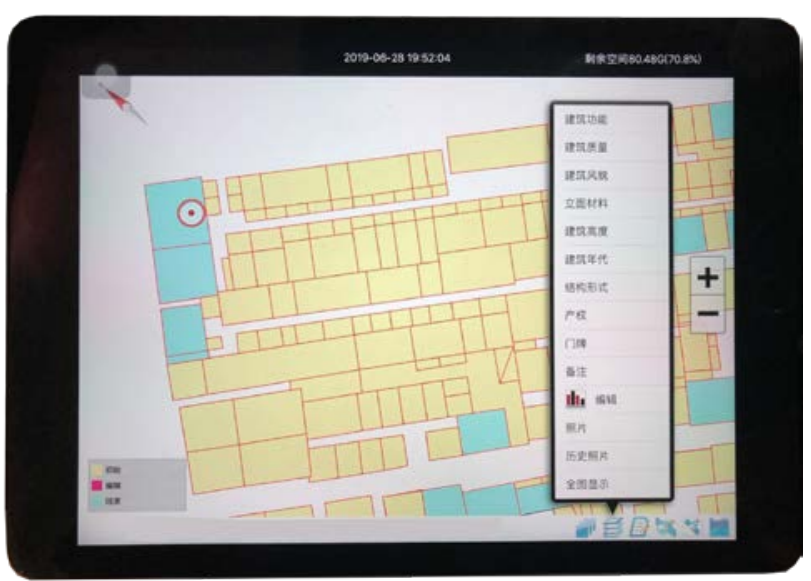

Figure 3 Mobile Terminal Research Tool interface

Mobile terminal research tools mainly complete the following functions, such as map display, editing and operation, data acquisition, editing and query, GPS positioning, real-time display of thematic maps and so on.

\subsubsection{The Function of Map Loading, Display and Editing}

Use the handheld device to read, and then preprocess to generate the MSF database file. Realize the map operation functions such as display, translation, dynamic translation, zoom in, zoom out and so on.

\subsubsection{GPS Positioning and Calibration Function}

The software has the ability to use the equipment GPS to locate and follow, so that it is convenient for researchers to determine their own position on the spot. At the same time, GPS following reduces the inconvenience caused by zooming and translating topographic maps on a smaller screen, and greatly facilitates the development of research.

\subsubsection{Functions of Data Editing and Query}

The user can input the information of the designated building, and the input fields and default values are determined according to the rules set during the data preprocessing. Input data is written into MSF database in real time to avoid accidental loss of data. The input of the data corresponds to the layer proposed above. In addition, it is necessary to standardize the input of researchers in strict accordance with database standards. The research system also provides the function of taking and storing photos.

\subsubsection{Function of Uploading Research Data}

After the data entry is completed, the research data can be automatically uploaded to the server through the connection between the handheld device and the server.

\subsection{PC-side Data Management Tool}

"PC-side data management tool" can support managers and technicians to carry out value evaluation, grading evaluation and data reference, historical building archives export and other functions. After the field data collection is completed, the mobile terminal MSF data is uploaded to the server.

\subsubsection{Value Evaluation and Grading Evaluation}

Based on the value evaluation standard system of historical buildings, the PC data management tool provides a value evaluation module. Researchers can easily evaluate historical buildings according to the results of the survey, evaluate their value, and quantify and grade them.

\subsubsection{Display and Query of Database}

Select the building or courtyard in the state of software editin, and then it will pop up to display the relevant information and photos of the dialog box, which facilitate the query of all kinds of information. Due to the display of the corresponding photos, managers can easily check the entered information, and the errors found can be corrected in a timely manner.

\subsubsection{The Output of Historical Building Archives}

According to the different grades of architectural evaluation, the software can export different architectural archives-generally based on historical architectural archives. Through the configuration of historical building file template, it carries on the automatic numbering, information filling and output, which takes the courtyard as the unit. The output format is word 
format, which is convenient for later adjustment and modification.

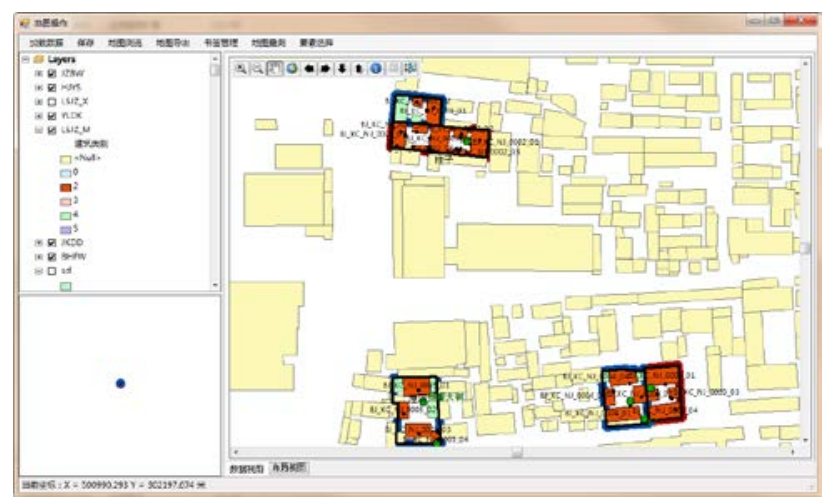

Figure 4 PC-side Data Management Tool interface

\subsection{User Operation Manual}

The purpose of the user operation manual is to make it convenient and intuitive for the user to understand the functional modules, usage and matters needing attention of the whole system. For example, when taking a photo, you should pay attention to the angle, light, location, and so on. The representative buildings in Beijing, such as quadrangle dwellings and industrial heritage, the architectural composition of different types of buildings, the names of the main bodies of the buildings, the names of the details of the buildings, the names of the elements of the historical environment, and so on.

The above five parts are closely related and form a whole. The "standard system" is rooted in the "utility", and the "operation manual" guides the user "behavior". In the process of using the tool, preset standards continue to regulate the user's behavior. The "mobile terminal" collects data, and the "PC terminal" processes and analyzes the data. The two tools can synchronize information with the help of the Internet and cloud servers, and the cloud server can store the information output by both tools. The whole system realizes the standardization of the whole process of the general survey and identification of historical buildings, and realizes the data of the basic data of historical buildings with the help of database, cloud server, Internet, application and other tools. It can be predicted that with the popularization of 5G technology in the future, this technology can have more application and upgrade space, and it will provide the necessary support for the comprehensive digitization of cultural heritage resources(Sun, Z.W., 2013).

\section{CONCLUSION}

Beijing is the capital of China, it is an ancient capital with a history of more than 3000 years, and its cultural heritage resources are very rich. In the "Beijing Urban Master Plan (2016-2035)", it is proposed to expand and enrich the contents of the protection of famous historical and cultural cities, strengthen the protection of historical buildings, and establish a long-term mechanism for evaluating excellent historical buildings. According to this requirement, it is of great significance to study the working standards and develop the corresponding supporting techniques for the general survey and identification of historical buildings. It is hoped that this paper can convey our thinking and research results to our professional colleagues. In addition, we look forward to the promotion and application of this method, so as to promote the protection and management of cultural heritage towards comprehensive data.

\section{REFERENCES}

Xu, H., Yang, L.X., Fang, Z.X., 2002. Discuss about the support technology of digital urban planning system. Journal of Wuhan university (engineering science), 2002(05), pp. 43-46.

Sun, H.J., Zhang, Z.H., Liu. J., 2013. Digital technology system and its application in urban planning management strategy research. Modern urban research, 2013(10), pp. 5-10.

Sun, Z.W., 2013. Network mechanism for urban reality space and virtual space planning implications. Journal of planner, 29 (02), pp. 43-47.

Revised June 2019 